\title{
Assessment of the physico-chemical quality and extent of algal proliferation in water from an impounding reservoir prone to eutrophication
}

\author{
Mohun Ballah, Vishwakalyan Bhoyroo and Hudaa Neetoo* ${ }^{*}$
}

\begin{abstract}
Background: Piton du Milieu (PdM) impounding reservoir is suspected to be eutrophic based on the elevated level of orthophosphate and nitrate. Water supplies from three adjacent rivers are primarily thought to contribute to the nutrient enrichment of the reservoir. It is also suspected that there is leaching of orthophosphate, nitrate and organic matter into the rivers during rainfall events and also as a result of anthropogenic activities within the catchment area. The aim of this study was to ascertain the impact of nutrient loading on the water quality of PdM water and on the population of freshwater microalgae in the reservoir. The enumeration and identification of algae from PdM were performed by differential interference contrast microscopy. Dissolved oxygen (DO) and $\mathrm{pH}$ were determined by electrometric methods, whereas nutrient levels, silica and total organic carbon (TOC) were determined by instrumentation techniques.
\end{abstract}

Results: Annual mean orthophosphate, nitrate and total organic carbon input from the three feeders within the catchment area of PdM reached levels as high as $0.09 \mathrm{mg} / \mathrm{L}, 0.4 \mathrm{mg} / \mathrm{L}$ and $2.62 \mathrm{ppm}$ respectively. Over a 12-month period, mean TOC concentration in the reservoir was $2.32 \mathrm{ppm}$ while the mean algal cell count was $4601 \mathrm{cell} s / \mathrm{mL}$. The dominant algal species identified were Oscillatoria, Cyclotella, Navicula and Cosmarium.

Conclusion: This study highlights the trophic state of the reservoir water and clearly points to the need for constant monitoring in order to avoid the occurrence of an impending harmful algal bloom.

Keywords: Algae, Proliferation, Reservoir, Mauritius

\section{Background}

The extensive use of fertilisers in the agricultural sector and the development of farming activities within close proximity to water catchment areas have contributed to a significant enrichment of our water resources resulting in eutrophication. Enrichment of water by nutrients such as phosphate and nitrate leads to the rapid and profuse growth of microalgae species, which induces an undesirable disturbance in the balance of aquatic organisms (Volterra et al. 2002). Indeed, eutrophication can lead to algal blooms and the direct consequence is an excess of oxygen consumption near the bottom of the water body (Volterra et al.

\footnotetext{
* Correspondence: s.neetoo@uom.ac.mu

Department of Agricultural and Food Sciences, Faculty of Agriculture, University of Mauritius, Réduit, Moka 80837, Mauritius
}

2002). The proliferation of algae also deteriorates the surface water quality creating colour, odour and taste problems as well as clogs the filters of water treatment plants (Volterra et al. 2002). Some algal species are also toxic to fish, animals and man, due to certain toxin-producing species of cyanobacteria. Microalgae blooms also cause hypoxia of the water system and are harmful to other aquatic species (Palmer 1960). Hypoxic systems can lead to disastrous economic consequences for countries relying on aquaculture and fishing as a source of food and livelihood. Eutrophication can also lead to reduced recreational use of water systems and increased water treatment costs (Dodds 2002). The concentration of nutrients in the water changes during eutrophication. If either all the phosphorous or nitrate becomes totally bound to the aquatic life, it will not be

(c) The Author(s). 2019 Open Access This article is distributed under the terms of the Creative Commons Attribution 4.0 International License (http://creativecommons.org/licenses/by/4.0/), which permits unrestricted use, distribution, and reproduction in any medium, provided you give appropriate credit to the original author(s) and the source, provide a link to the Creative Commons license, and indicate if changes were made. The Creative Commons Public Domain Dedication waiver (http://creativecommons.org/publicdomain/zero/1.0/) applies to the data made available in this article, unless otherwise stated. 
available for further growth of algae, and hence, this nutrient is called the limiting factor (Volterra et al. 2002). Generally, phosphorus tends to be the limiting factor for phytoplankton in fresh waters (Volterra et al. 2002). When phosphorus is the limiting factor, a phosphate concentration of $0.01 \mathrm{mg} / \mathrm{L}$ is enough to support algal growth while concentrations from 0.03 to $0.1 \mathrm{mg} / \mathrm{L}$ or higher will likely promote blooms (Volterra et al. 2002).

Piton du milieu (PdM) impounding reservoir is one of the main sources of water for domestic freshwater supply. There are several anthropogenic activities within the catchment area of PdM reservoir that are thought to contribute to eutrophication problems, namely animal husbandry and sugarcane and vegetable cultivation. Agricultural practices contribute to the enrichment of water bodies by the leaching of chemical and organic fertilisers (Fried et al. 2003). Consequently, fertilisers which are applied to the agriculture lands located in the catchment of PdM eventually leach into rivers through heavy rainfall run-offs which reach the reservoir and accumulate therein.

Moreover, overhead irrigation of sugar cane and vegetable plantations along the feeders can significantly worsen the run-off of fertilisers into rivers. The unsanitary disposal of manure from the animal husbandry represents another diffuse source of nutrients within the catchment area of PdM. The run-off and storm overflows from the pastures ultimately find their way towards the nearby impounding reservoir. The level of orthophosphate and nitrate from the rivers' water flowing into the reservoir may be considered as one of the factors that may cause algal proliferation (Yokota 1990).

Previously, a study was undertaken by Jawaheer et al. (2010) to identify and enumerate microalgae at La Nicoliere impounding reservoir. The report concluded that $\mathrm{La}$ Nicoliere was facing an algal pollution problem that warranted urgent assessment for remedial actions (Jawaheer et al. 2010). Humbert (2012) reported that the concentration of reactive phosphorous in the waters at La Nicoliere reservoir frequently reached the levels of up to $100 \mu \mathrm{g} / \mathrm{L}$, which represents a potential threat of an algal bloom.

The purpose of the study was thus to investigate the impact of nutrient input on the physico-chemical quality and the level of algae in water of PdM reservoir over a 12 -month period. Specifically, the study purported to enumerate and identify the microalgae species that could be present in the water system and adversely affect water treatment operations, public health and the ecosystem.

\section{Results and discussion}

Variation in the level of nutrients in reservoir water and relationship with algal cell density Changes in the level of nitrate

From February to April, the concentration of nitrate was at $0.5 \mathrm{mg} / \mathrm{L}$, which decreased to $0.4 \mathrm{mg} / \mathrm{L}$ in May and remained unchanged till June. In July, the nitrate level decreased to $0.1 \mathrm{mg} / \mathrm{L}$ and plateaued till January. When averaged over the year, the concentration of nitrate was found to be $0.3 \mathrm{mg} / \mathrm{L}$, which is indicative of nitrate exceeding the required minimum levels $(0.01 \mathrm{mg} / \mathrm{L})$ necessary to support the growth of most algal species (Sigee 2004). Mean nitrate level of $0.3 \mathrm{mg} / \mathrm{L}$ and the annual average influx of nitrate of $0.4 \mathrm{mg} / \mathrm{L}$ from Rivière Vacoas, Rivière Bateau and Rivière Chevrette could thus favour an algal bloom. In fact, we observed that the dynamics of algal density closely followed the changes in the level of nitrate. Algae population decreased gradually from February $(7195$ cells $/ \mathrm{mL})$ to June $(3240$ cells $/ \mathrm{mL})$ and oscillated between 3240 and 3504 algal cells $/ \mathrm{mL}$ from June to September (Fig. 1). In October, algal cell density decreased to 1139 cells $/ \mathrm{mL}$ and almost plateaued till November (1186 cells $/ \mathrm{mL})$. This was followed by a peak in algae population in December (6265 cells $/ \mathrm{mL}$ ) and January (7260 cells $/ \mathrm{mL}$ ). Overall, a moderate but insignificant correlation $(r=0.4875, P>0.05)$ was observed between algal cell density and nitrate levels in PdM.

\section{Changes in the level of orthophosphate}

Several authors (Kristiansen 1996; Fried et al. 2003) have mentioned that orthophosphate is the limiting nutrient in freshwater aquatic systems, i.e. if all phosphorus is used up, algal growth will cease irrespective of the level of other nutrients. The natural level of orthophosphate typically ranges from 0.005 to $0.05 \mathrm{mg} / \mathrm{L}$, and a level of 0.08 to $0.10 \mathrm{mg} / \mathrm{L}$ is thought to favour algal blooms (Hession and Storm 2000). The average loading of orthophosphate from Rivière Bateau, Rivière Chevrette and Rivière Vacoas into the reservoir ranged from 0.07 to $0.4 \mathrm{mg} / \mathrm{L}$. Specifically, in the months of March, July, December and January, the level of orthophosphate loading from the three rivers ranged from 0.03 to $0.22 \mathrm{mg} / \mathrm{L}$, which represents a trophic status that favours eutrophication of standing waters (Dodds 2002). As far as the reservoir water was concerned, the concentration of orthophosphate increased from February $(0.04 \mathrm{mg} / \mathrm{L})$ to June $(0.12 \mathrm{mg} / \mathrm{L})$ and gradually decreased to $0.07 \mathrm{mg} / \mathrm{L}$ in October followed by a rise in November $(0.14 \mathrm{mg} / \mathrm{L})$ to January $(0.20 \mathrm{mg} / \mathrm{L})$ (Fig. 1). The mean concentration of orthophosphate of $0.09 \mathrm{mg} / \mathrm{L}$ recorded in the reservoir likely had a considerable influence on mean algal cell density at S1 $(4350$ cells $/ \mathrm{mL}), \mathrm{S} 2$ (4885 cells $/ \mathrm{mL}), \mathrm{S} 3(4695$ cells $/ \mathrm{mL})$, S4 (4978 cells $/ \mathrm{mL}$ ) and S8 (5613 cells $/ \mathrm{mL})$ during the 12 months (Fig. 1). Peaks in algal cell density recorded in December (6265 cells $/ \mathrm{mL}$ ) and January (7260 cells $/ \mathrm{mL}$ ) were probably related to orthophosphate levels reaching up to 0.13 and $0.20 \mathrm{mg} / \mathrm{L}$ respectively. Overall, a weak but insignificant correlation $(r=0.1627, P>0.05)$ was observed between algal cell density and orthophosphate levels in PdM over the 12-month period. Nevertheless, the mean orthophosphate level of the reservoir exceeded the 


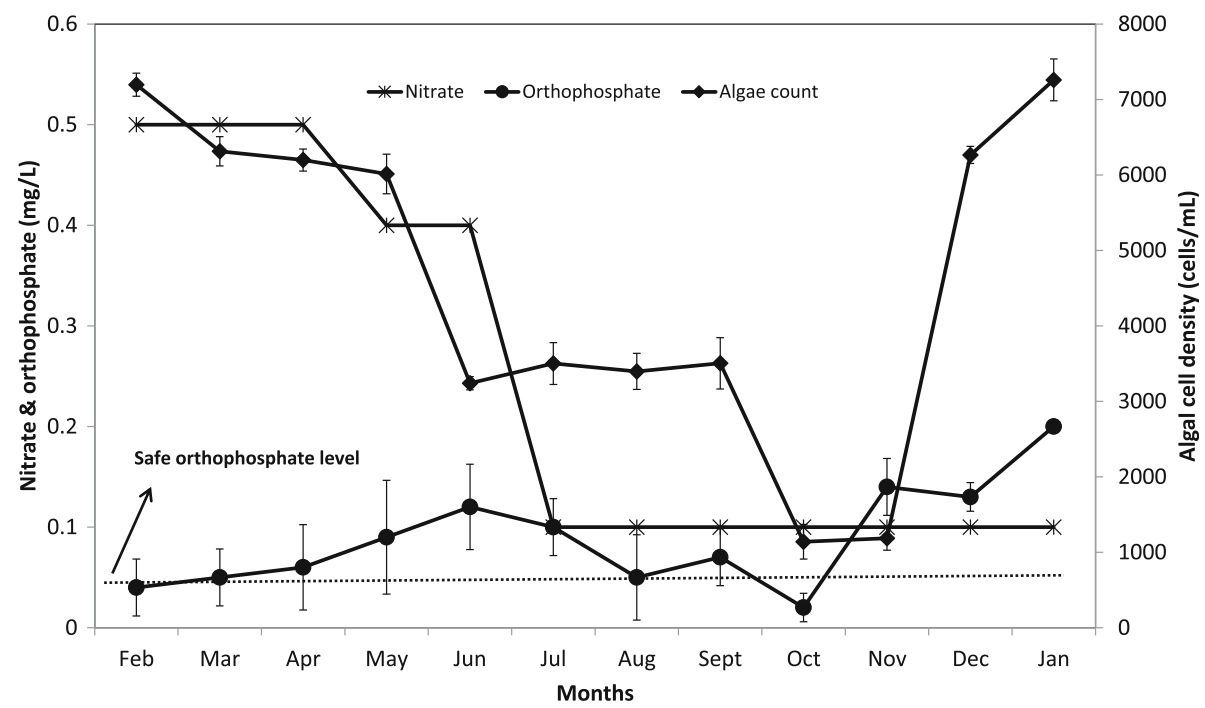

Fig. 1 Relationship between orthophosphate, nitrate level of water and algal growth

safe level $(0.05 \mathrm{mg} / \mathrm{L})$ represented by the dotted line during many instances. PdM can thus be perceived as constantly under the threat of eutrophication due to its high mean orthophosphate level $(0.09 \mathrm{mg} / \mathrm{L})$ and the annual average influxes of orthophosphate $(0.08 \mathrm{mg} / \mathrm{L})$ from Rivière Vacoas, Rivière Bateau and Rivière Chevrette. Long-term eutrophication can therefore be prevented if orthophosphate level is below $0.05 \mathrm{mg} / \mathrm{L}$ (Hession and Storm 2000).

\section{Effects of rainfall on algal cell density at PdM reservoir}

The water level in PdM reservoir ranged from 80 to $100 \%$ over the 12-month period (data not shown). Average rainfall in the catchment fluctuated throughout the 12-month period with peaks of 405.0, 309.5 and $689.8 \mathrm{~mm}$ in March, July and January respectively (Fig. 2). The changes in algal density in PdM reservoir appeared to closely follow the trend in heavy rainfall events (Fig. 2). For example, periods of heavy rainfall in March (405.0 mm), December (520.4 $\mathrm{mm})$ and January $(689.8 \mathrm{~mm})$ led to a corresponding increase in mean algae density of 6313, 6265 and 7560 cells/ $\mathrm{mL}$ in the same months. Heavy rainfall is thought to be associated with the generation of nutrient-rich run-offs originating from agricultural lands within the catchment area of PdM. These run-offs subsequently leach into the three rivers flowing into the reservoir, thereby contributing to the enrichment of its water (Yokota 1990). Hence,

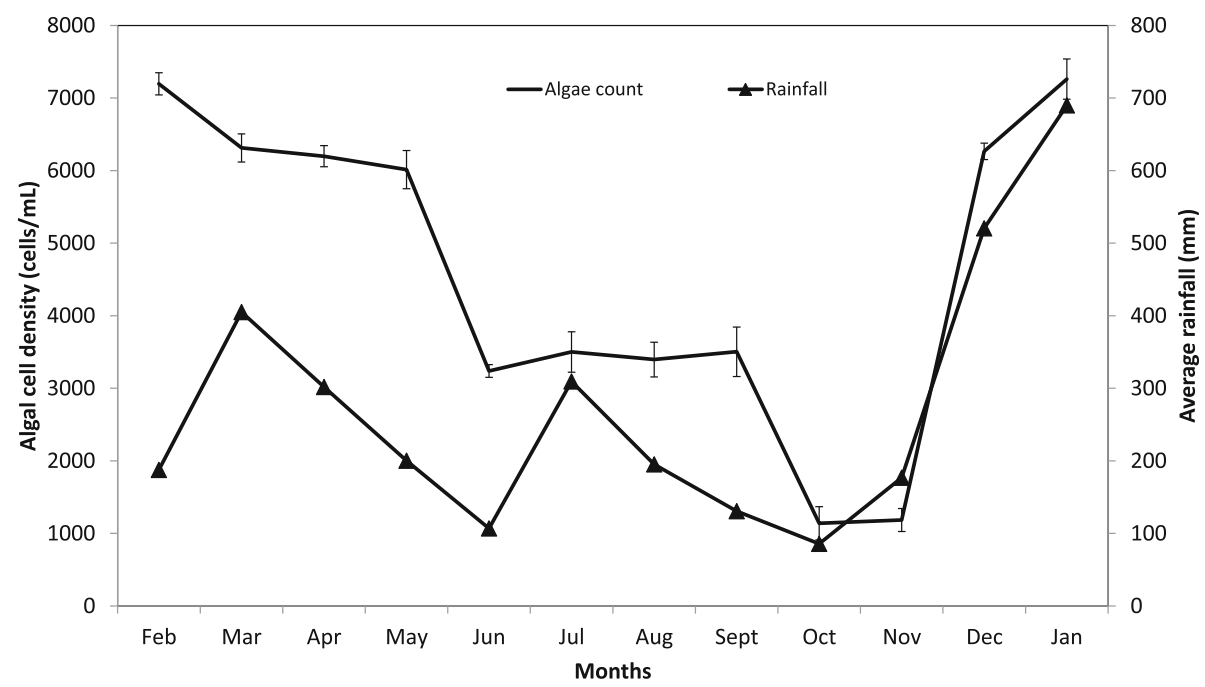

Fig. 2 The effects of rainfall on algal cell density at PdM reservoir 
the observed rise in algae concentration at PdM was likely related to the enrichment of the reservoir after each heavy rainfall event. Overall, we observed a moderate but significant correlation $(r=0.6522, P<0.05)$ between algal cell density and rainfall in PdM over the 12-month period. Table 1 shows the strength of correlation between algal density and various water quality parameters.

\section{Changes in physico-chemical characteristics of reservoir water and relationship with algal cell density}

Over the study period, the mean temperature, $\mathrm{pH}$ and dissolved oxygen of PdM water were $23.3{ }^{\circ} \mathrm{C}, 7.36$ and 7.85 $\mathrm{mg} / \mathrm{L}$ respectively (Fig. 3). Surface water temperature oscillated between 19.9 and $27.9^{\circ} \mathrm{C}$ throughout the period of the study which is conducive for the growth of certain algal species particularly the cyanobacteria also known as blue-green algae (Bellinger and Sigee 2010). pH was close to neutrality (7.36) and was almost constant during the 12 months. Since blue-green algae are known to tolerate a broad $\mathrm{pH}$ range (Bellinger and Sigee 2010), PdM could support algal growth year-round. The mean dissolved oxygen level is indicative of oxygen saturation within the water column. The dissolved oxygen is thought to be influenced by various processes such as the supply of oxygen through algal photosynthesis and inflowing rivers; re-aeration at water surface; uptake of oxygen through respiration of algae, bacteria, macrophytes and fish; nitrification to nitrate and nitrite; and decomposition of detritus, dissolved organic matter and organic sediments at the bottom of the reservoir (Volterra et al. 2002). High nutrient levels promote blooms of photosynthetic life, which upon death are decomposed by the aerobic bacteria; hence, their proliferation can lead to decreased dissolved oxygen levels (Rathore et al. 2016).

\section{Variation in the level of chemical compounds and relationship with algal cell density}

The variation in the level of silica, total organic carbon (TOC) and algae over the 1-year duration is depicted in Fig. 4. The level of silica was almost constant from February to March (10.0-10.3 mg/L) and decreased sharply to $4.2 \mathrm{mg} / \mathrm{L}$ in May (Fig. 4). In the months of June to November, the level had attained $8.2-9.7 \mathrm{mg} / \mathrm{L}$ before declining rapidly to a final level of $1.6 \mathrm{mg} / \mathrm{L}$ in January. Silica forms the basis of the structural component of cell walls of diatoms. The moderate level of diatoms Cyclotella $(108$ cells $/ \mathrm{mL})$, Pinullaria $(60$ cells $/ \mathrm{mL})$ and Navicula (45 cells $/ \mathrm{mL}$ ) in PdM indicates an adequate availability of silica.

Total organic carbon (TOC) level ranged from 0.92 to $3.76 \mathrm{ppm}$ during the study period. The average TOC in the reservoir was $2.32 \mathrm{ppm}$, which may be associated with pollution by soluble organic wastes leaching from nearby animal farms. Consequently, TOC could also potentially impact on the proliferation and dominancy of some of the algal species enumerated in this study (Palmer 1964). The presence of algae and TOC levels above $4 \mathrm{ppm}$ could likely produce elevated amounts of disinfection by-products such as carcinogenic trihalomethanes (THMs) in the drinking water distribution system (Volterra et al. 2002). THMs are produced when methane, released during bacterial decomposition of organic matter in water, reacts with chlorine-based disinfectants by substitution reaction or halogenation (Cox 1965).

Variation in algal cell density at different sampling points In this study, to understand the distribution of phytoplankton population in $\mathrm{PdM}$ and its trophic status, water samples were collected from different sampling stations:

Table 1 Strength of correlation between different variables and algal density

\begin{tabular}{|c|c|c|c|c|}
\hline Months & Average rainfall $(\mathrm{mm})$ & Nitrate $(\mathrm{mg} / \mathrm{L})$ & Orthophosphate (mg/L) & Algae count (cells $/ \mathrm{mL}$ ) \\
\hline February & 187.5 & 0.5 & 0.04 & 7195 \\
\hline March & 405.0 & 0.5 & 0.05 & 6313 \\
\hline April & 301.8 & 0.5 & 0.06 & 6198 \\
\hline May & 200.3 & 0.4 & 0.09 & 6013 \\
\hline June & 106.9 & 0.4 & 0.12 & 3240 \\
\hline July & 309.5 & 0.1 & 0.10 & 3501 \\
\hline August & 195.2 & 0.1 & 0.05 & 3397 \\
\hline September & 130.6 & 0.3 & 0.07 & 3504 \\
\hline October & 85.6 & 0.1 & 0.02 & 1139 \\
\hline November & 176.7 & 0.1 & 0.14 & 1186 \\
\hline December & 520.4 & 0.1 & 0.13 & 6265 \\
\hline January & 689.8 & 0.1 & 0.20 & 7260 \\
\hline Correlation coefficient $(R)$ with algal count & 0.6522 & 0.4875 & 0.1627 & - \\
\hline
\end{tabular}




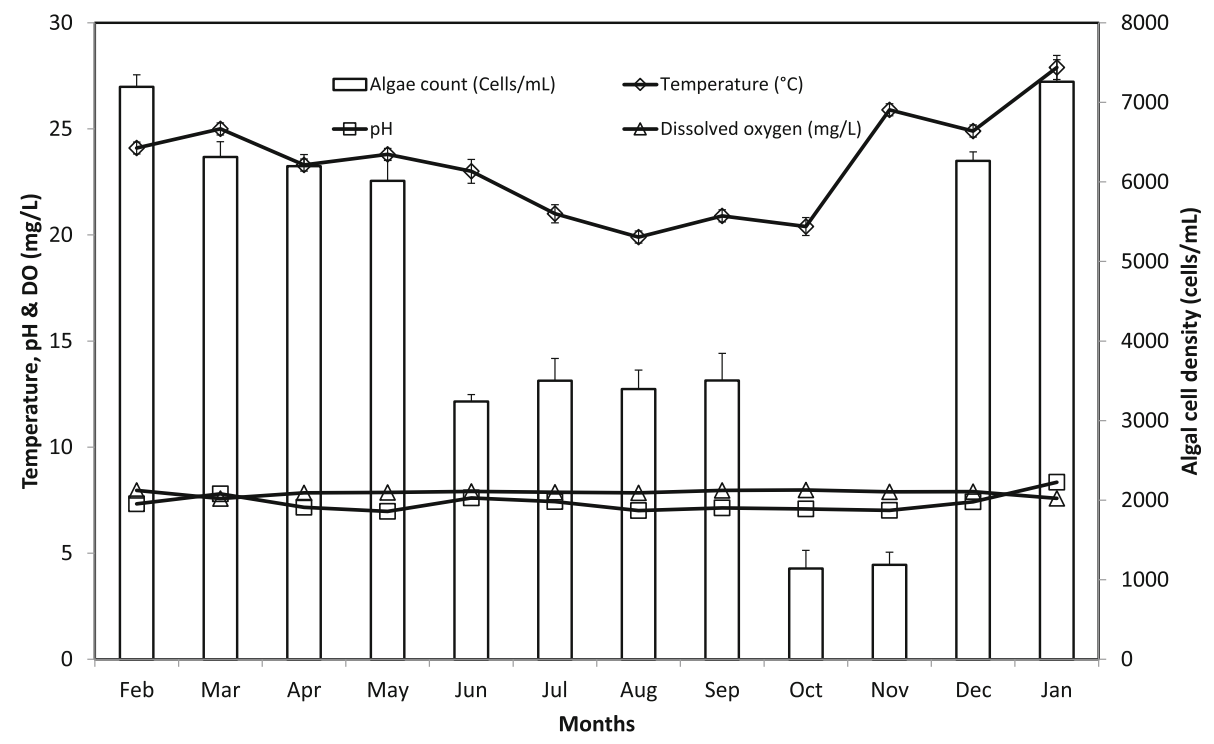

Fig. 3 Relationship between $\mathrm{pH}$, temperature, DO of water and algal growth

downwind end of the reservoir (S1 and S2), delta of rivers feeding into PdM (S3 and S4) and reservoir euphotic zone (S8). Sample stations S1 and S2 enabled the determination of buoyant algal matter accumulation at the downwind end of the reservoir. River inflows are characterised by high levels of inorganic nutrients (Bellinger and Sigee 2010); hence, monitoring of algae at the delta of the rivers was conducted at sampling stations S3 and S4. Sampling station S8 was the deepest point in the lake, and water samples were thus collected at different depths of the euphotic zone. Sampling from the euphotic zone of the reservoir enabled the determination of algal species diversity and population inhabiting the epilimnion (actively growing photosynthetic populations) (Bellinger and Sigee 2010).

The algal concentration in water sampled at S1, S2, S3, S4 and S8 followed very similar trends during the studied period as shown in Fig. 5. The algal cell density gradually decreased from February to May (50,362 to 42,085 cells $/ \mathrm{mL}$ ) followed by a sharp decline in June by 27,683 cells $/ \mathrm{mL}$. A slight increase from 22,679 to 24,508 algal cells/mL was observed in the waters of PdM from June to July, followed by a plateau over the period spanning July to September before dropping to 7971 algal cells/mL in October. There was no noticeable change in algal cell density

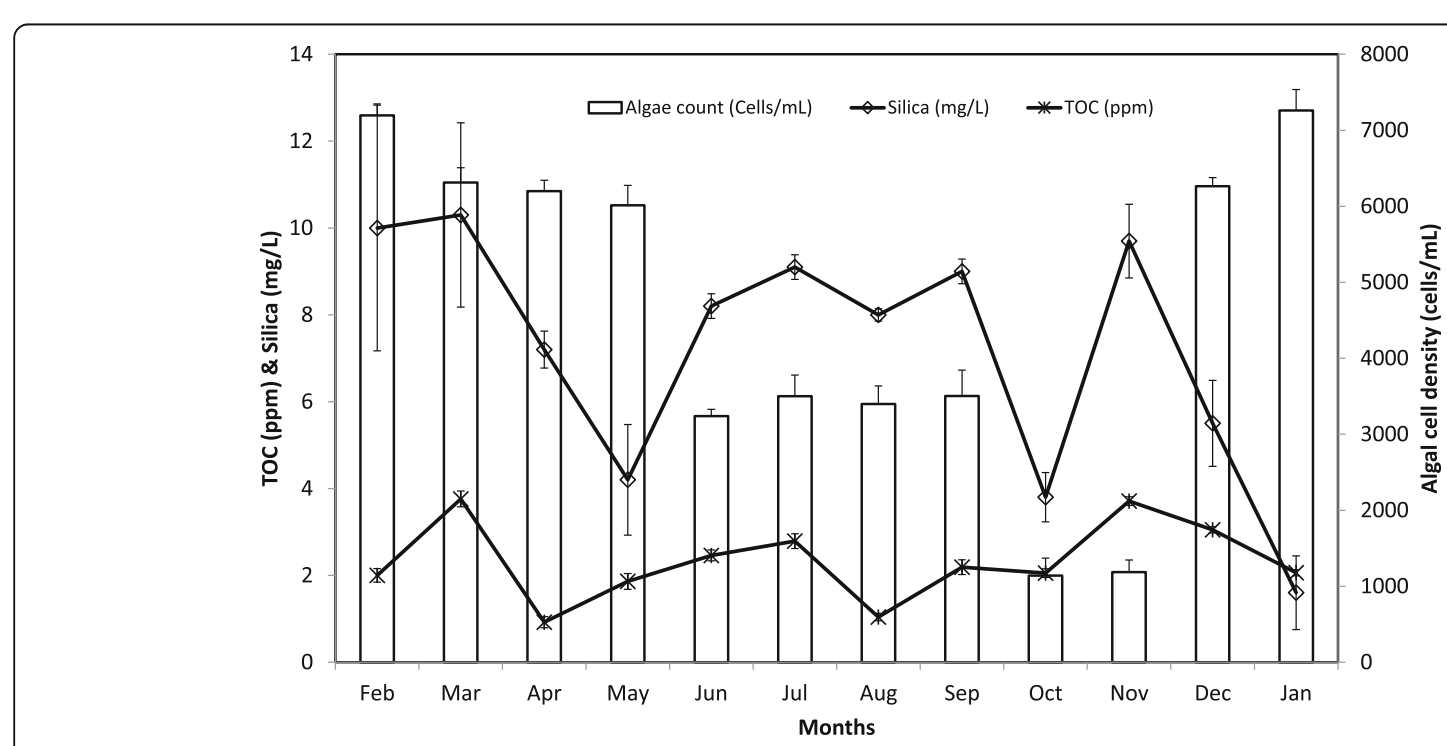

Fig. 4 Relationship between TOC, silica level of water and algal growth 


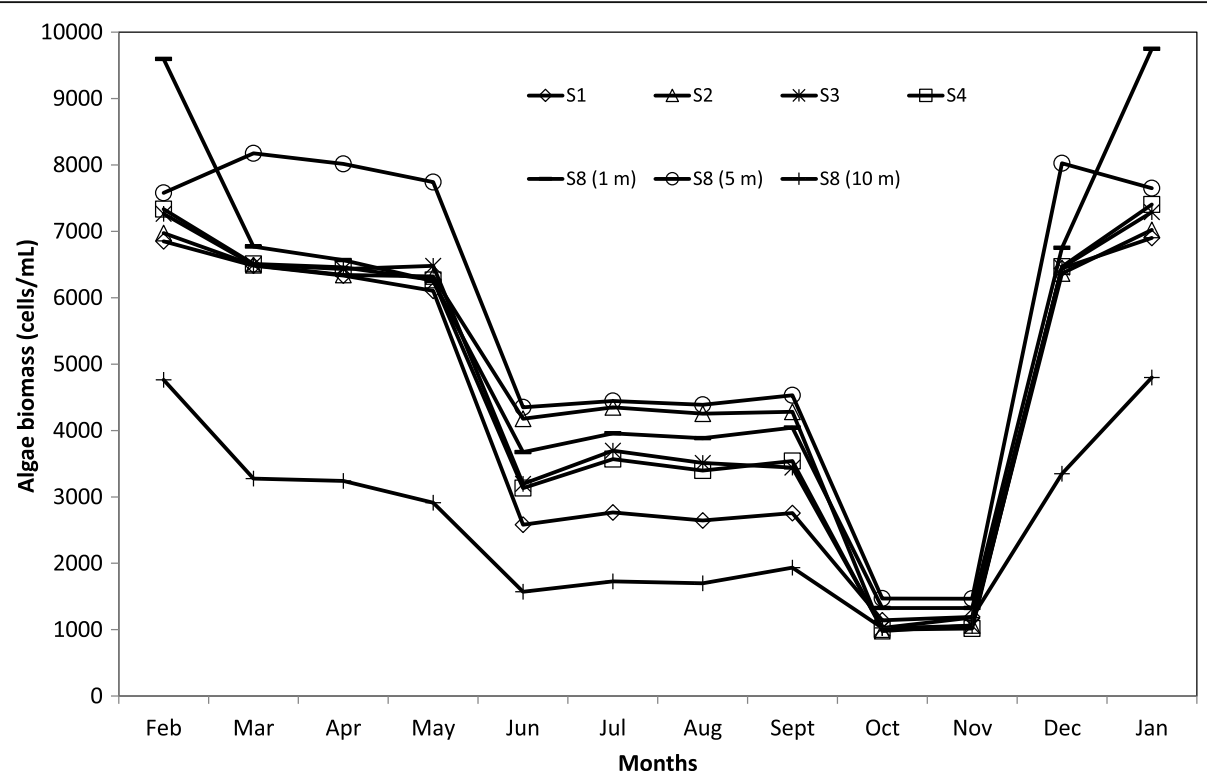

Fig. 5 Trend in algae cell density at various sampling stations in the vicinity of PdM

over the period of October and November. However, a considerable rise in population density of 42,514 cells $/ \mathrm{mL}$ was observed from November to January of the following year.

The higher algal population noted at S3 and S4 in February, March, December and January is likely related to their proximity to Rivière Bateau and Rivière Vacoas/Rivière Chevrette respectively. It can thus be inferred that nutrient loadings from Rivière Bateau, Rivière Vacoas and Rivière Chevrette contribute considerably to the proliferation of algae at S3 and S4 with a mean algal cell count of 4695 and 4628 cells/ $\mathrm{mL}$ respectively. Yokota (1990) reported that excessive algal proliferation in impounding reservoirs could be attributed to the heavy loading of nutrients by inflows from rivers. The annual mean algal cell count at S2 (4885 cells $/ \mathrm{mL}$ ) was higher than at S1 (4350 cells/ $\mathrm{mL}$ ) possibly due to the effect of wind-induced turbulences, which likely drifted the algae on the surface of the water from S3 to S2.

The average algal cell count at $1-\mathrm{m}, 5-\mathrm{m}$ and $8-\mathrm{m}$ depth of sampling station S8 was 5325, 5653 and 2624 cells $/ \mathrm{mL}$ respectively. This variation in algal cell density within the water column is probably attributed to the migration of epilimnion algae to a depth of $5 \mathrm{~m}$ to benefit from the favourable conditions of light, temperature and nutrients prevailing within the water column (Sigee 2004). The algae cell density recorded at $1 \mathrm{~m}$ likely resulted from buoyant algae brought to the surface from the deeper region of the water column by wind-induced turbulence (Sigee 2004). The lower algae cell count recorded at $10 \mathrm{~m}$ (2624 cells $/ \mathrm{mL}$ ) could either be due to the decreasing light intensity at increasing reservoir depth or algae undergoing senescence (Sigee 2004).

\section{Dominant algal species in reservoir water}

The dominant algal species identified in raw water collected at sampling station S8 over the 12-month period were Oscillatoria (Cyanobacteria), Cyclotella (diatom), Navicula (diatom), Pinullaria (diatom) and Cosmarium (Chlorophyta) (Fig. 6), and their averaged cell count was $621,108,45,60$ and 783 cells $/ \mathrm{mL}$ respectively. Cosmarium $(783$ cells $/ \mathrm{mL})$ and Oscillatoria $(621$ cells $/ \mathrm{mL})$ were the two most dominant and common species followed by Cyclotella (108 cells $/ \mathrm{mL})$, Pinullaria (60 cells $/ \mathrm{mL}$ ) and Navicula (45 cells/mL). These species of dominant algae were not present at levels that could pose a problem to the water treatment facilities at PdM (Palmer 1960). However, Oscillatoria is a cyanobacterial microalga which imparts an off-taste and odour in water used for drinking purposes (Mohamed 2016). Additionally, when present in large numbers, it can clog filters used in water treatment processes and some members of the Oscillatoria group are known to produce toxins (Gavrilova et al. 2002). The proliferation of the diatom Cyclotella and Navicula in reservoirs and lakes can also cause problems of filter blocking in water treatment works (Bellinger and Sigee 2010). The presence of Cosmarium in large numbers in reservoirs also represents a nuisance in terms of off-taste and odour problems in water (Palmer 1960).

The dominance of certain species was not only attributed to the moderate to high inorganic nutrient status of the reservoir, but also to the presence of soluble organic pollution in the water in the form of total organic 


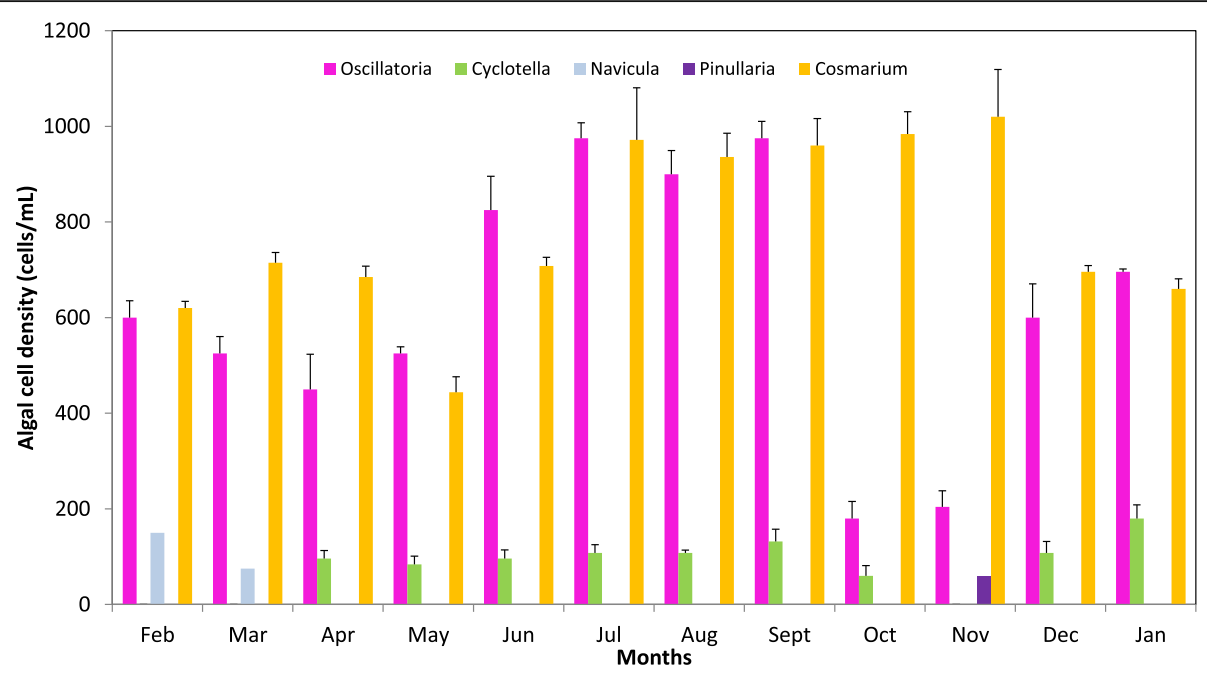

Fig. 6 Dominant algae species identified at sampling station S8 prior to the treatment of raw water

carbon (Bellinger and Sigee 2010). Mean TOC level in the reservoir for the period February to January was $2.32 \mathrm{ppm}$, which could have favoured the proliferation of algae Oscillatoria. According to Palmer (1964), organic pollution tends to influence the microalgal flora just as effectively as inorganic nutrients. Oscillatoria, Cyclotella and Navicula are relatively tolerant of organic pollution (Palmer 1964; Bellinger and Sigee 2010) and hence may occur in waters contaminated by soluble organic wastes. The annual average level of orthophosphate and nitrate in the reservoir was 0.09 and $0.3 \mathrm{mg} / \mathrm{L}$ respectively. Such nutrient-rich conditions could have been favourable for the growth of Cosmarium, which typically occurs in mesotrophic and eutrophic lakes (Bellinger and Sigee 2010). Pinullaria, on the other hand, is a ubiquitous diatom found in nutrient-poor or nutrient-rich waters (Bellinger and Sigee 2010).

\section{Conclusion}

This study highlights the eutrophic state of PdM reservoir water and clearly points to the need for constant monitoring in order to avoid the occurrence of an impending algal bloom. Orthophosphate (including all forms of phosphorous) and nitrate loading into the reservoir must be reduced by the judicious use of fertilisers on agricultural land in the catchment areas of PdM and by preventing the downstream discharge of manure from the animal husbandry into the inflowing rivers to the reservoir. Strict monitoring for algal species posing problems for water treatment facilities and threats to public health is also recommended at PdM. TOC levels should be diligently monitored to prevent the formation of carcinogenic trihalomethanes in drinking water. The permit allocations for land use and development in the catchment of Piton du Milieu should also be reconsidered by the responsible ministry and authorities so that concrete measures are implemented to relocate the animal husbandry and agricultural lands. It is also advised that the Ministry of Environment and relevant NGOs promote more re-forestation activities in order to minimise run-offs, thereby maintaining a good water quality in the reservoir.

\section{Materials and methods \\ Site description}

PdM is situated in the central plateau benefitting from a mean annual precipitation exceeding $3600 \mathrm{~mm}$, a mean annual temperature of $20.5^{\circ} \mathrm{C}, 6.5 \mathrm{~h}$ sunshine per day and over $82 \%$ humidity (Liedholm 2007). The super humid catchment surrounding PdM is mostly covered with sugar cane fields (66\%), forest (33\%) and vegetable plantation (Liedholm 2007). Besides crop cultivation, another important anthropogenic activity upstream of the reservoir is animal husbandry. The water storage capacity of PdM is 2.99 million cubic meters and is supplemented with water from Rivière Vacoas, Rivière Bateau and Rivière Chevrette located upstream of the reservoir (WRU 2014). PdM is a reservoir constructed by damming Vacoas River with an 825 -m-long dam wall, and its deepest zone $(10 \mathrm{~m})$ is at the intake tower (Liedholm 2007).

\section{Sampling}

To understand the extent of nutrient loading from the inflowing rivers into PdM, sampling stations were established on the littoral of the reservoir and in the three feeders upstream of the lake. There were eight sampling stations, and their respective locations are indicated in Table 2. 
Table $\mathbf{2}$ Location of each sampling station

\begin{tabular}{ll}
\hline Sampling station & Location \\
\hline S1 & Downwind end of PdM reservoir \\
S2 & Downwind end of PdM reservoir \\
S3 & In PdM reservoir at the delta of Rivière Bateau \\
S4 & In PdM reservoir at the delta of Rivière Vacoas and \\
& Rivière Chevrette \\
S5 & Rivière Bateau upstream of Piton du Milieu \\
S6 & Rivière Vacoas upstream of Piton du Milieu \\
S7 & Rivière Chevrette upstream of Piton du Milieu \\
S8 & Intake tower of PdM reservoir
\end{tabular}

Sampling station S8 was located at the intake tower (deepest point) of the reservoir, and at S8, discrete samples were collected from the euphotic zone at $1 \mathrm{~m}, 5 \mathrm{~m}$ and $10 \mathrm{~m}$ using a Van Dorn volume sampler. Samples were collected in separate 1-L plastic containers for physical, chemical and biological analyses at intervals of 30 days between 09.30 a.m. to 13.00 p.m. over a period of 12 months. The samples were transported in light-proof isotherm box containing ice packs.

\section{Physico-chemical analyses}

Temperature measurements were made with a calibrated mercury-filled "Ertco ASTM3C" thermometer (Thermco ACC003C: USA), which was graduated for every $0.1{ }^{\circ} \mathrm{C}$. For dissolved oxygen (DO), a grab sample was collected in a 5 - $\mathrm{L}$ plastic container with minimum agitation, and the electrode (LE621galvanic sensor 01-915-721) of a calibrated "Mettler Toledo" DO meter (FG4 Five GO 01-915-721: USA) was inserted into the water sample. When the value on the screen of the meter was stable, it was recorded as milligram per litre DO (Eaton et al. 1995). $\mathrm{pH}$ of the water was determined with a calibrated "Mettler Toledo" pH meter (S220 Seven Compact pH/ Ion 30019029: Australia). Levels of total reactive phosphorus (orthophosphate), nitrate and silica were determined by "Hach" spectrophotometry (DR6000 UV VIS LPV441.9.00012: USA), and the optical density read at a wavelength of 880, 220 and $452 \mathrm{~nm}$ respectively (Eaton et al. 1995). Levels of total organic carbon were determined in parts per million by oxidative combustion method using "Teledyne Tekmar" APOLLO 9000 TOC Combustion Analyser (USA).

\section{Microbiological test parameter}

Microscopic examination was used to enumerate and identify living individual algal cells and colonies. One hundred millilitre of algal suspension was treated with Lugol's solution and sedimented in a stoppered 100-mL measuring cylinder for $48 \mathrm{~h}$ in darkness. After sedimentation, the top $90 \%$ of volume was carefully siphoned off without disturbing the settled algae, the remainder was shaken gently and $1 \mathrm{~mL}$ sub-sample was transferred to the Sedgwick-Rafter counting chamber. The sample was left to settle for $30 \mathrm{~min}$ before counting with the $\times 20$ objective of a "Leica" DM2500 differential interference contrast (DIC) microscope (Germany). The $\times 40$ and $\times$ 63 objectives were used to distinguish the morphological differences among algae to enable their identification. Dead algae lacking cell contents and the remains of diatom frustules were not counted. Microscopy combined with digital photomicrography was used to accurately identify algal species at the genus level on the basis of readily observable morphological features such as shape, motility, cell wall structure and colonial form (Bellinger and Sigee 2010). These features were compared with illustrations from standard identification keys to enable the identification of algal cells (Prescott 1954).

\section{Statistical analysis}

All analyses were conducted in two replicates. Where appropriate, a Pearson correlation was applied using GraphPad Prism 8 software as a measure of the linear correlation between the concentration of algae and other water quality parameters. Statistical significance was attributed to $P<0.05$.

\section{Additional files}

Additional file 1: Plates of selected algae species identified in PDM reservoir water. (DOCX $1043 \mathrm{~kb}$ )

Additional file 2: Original research data of test parameters analysed. (XLSX $20 \mathrm{~kb})$

\section{Abbreviations}

CWA: Central Water Authority; DO: Dissolved oxygen; NGO: Non-government organisation; PdM: Piton du Milieu; ppm: Parts per million; THMs: Trihalomethanes; TOC: Total organic carbon; UV: Ultraviolet; WRU: Water Resources Unit

\section{Acknowledgements}

Not applicable

\section{Funding}

The University of Mauritius funded this research. The Central Water Authority of Mauritius further supported the project in kind.

\section{Availability of data and materials}

All data generated or analysed during this study are included in this published article and its Additional files 1 and 2 .

Authors' contributions

SMB was involved in the data collection and analysis. VB assisted with the statistical analysis of data. MB and SHN were involved in the writing of the manuscript. All authors read and approved the final manuscript.

\section{Authors' information}

Not applicable

Ethics approval and consent to participate Not applicable 


\section{Consent for publication}

Not applicable

\section{Competing interests}

The authors declare that they have no competing interests.

\section{Publisher's Note}

Springer Nature remains neutral with regard to jurisdictional claims in published maps and institutional affiliations.

Received: 6 June 2018 Accepted: 26 November 2018

Published online: 10 January 2019

\section{References}

Bellinger EG, Sigee DC. Freshwater algae; 2010. https://doi.org/10.1002/ 9780470689554

Cox CR. Operation and control of water treatment processes. Geneva: World Health Organisation; 1965

Dodds WK. Freshwater ecology: concepts and environmental applications. A volume in aquatic ecology; 2002.

Eaton AD, Clesceri LS, Greenberg AE. Standard methods for the examination of water and wastewater. 19th ed. Washington, D.C.: American Public Health Association; 1995

Fried S, Mackie B, Nothwehr E. Nitrate and phosphate levels positively affect the growth of algae species found in Perry Pond. 2003. https://www. researchgate.net/publication/266894457_Nitrate_and_phosphate_levels_ positively_affect_the_growth_of_algae_species_found_in_Perry_Pond. Accessed 6 Feb 2018.

Gavrilova OV, Voloshko LN, Titova NN, Bedyagina OM, Gromov BV. Study of the toxic cyanobacterium Oscillatoria agardhii Gom. in culture. Int Journal Algae. 2002;4(3):93-103. https://doi.org/10.1615/interjalgae.v4.i3.60.

Hession WC, Storm DE. Watershed-level uncertainties: implications for phosphorus management and eutrophication. J Env Qual. 2000;29(4):1172. https://doi.org/ 10.2134/jeq2000.00472425002900040019x. Accessed 6 Feb 2018.

Humbert JF. Rapport déxpertise sur les reservoir déau utilises pour la production déau potable sur l'lle Maurice et sur Lúsine de traitement de léau de la Nicoliere. Paris: INRA; 2012.

Jawaheer S, Bhagooli R, Bahorun T. Survey of microalgae at La Nicoliere. Reduit: UOM; 2010.

Kristiansen J. Dispersal of freshwater algae-a review. Biogeography of freshwater algae; 1996. p. 151-7. https://doi.org/10.1007/978-94-017-0908-8_15.

Liedholm J. Primary production in freshwater reservoirs in Mauritius: Uppsala University; 2007. http://webcache.googleusercontent.com/search?q=cache. Accessed 6 Feb 2018

Mohamed ZA. Breakthrough of Oscillatoria limnetica and microcystin toxins into drinking water treatment plants - examples from the Nile River, Egypt. Water SA. 2016:42(1):161. https://doi.org/10.4314/wsa.v42i1.16.

Palmer CM. Algae in water supplies: an illustrated manual on the identification, significance, and control of algae in water supplies; 1960.

Palmer CM. Algae in water supplies of the United States. In: Algae and man; 1964. p. 239-61. https://doi.org/10.1007/978-1-4684-1719-7_12.

Prescott GW. How to know the fresh-water algae; an illustrated key for identifying the more common fresh-water algae to genus, with hundreds of species named pictured and with numerous aids for their study; 1954. https://doi.org/10.5962/bhl.title.5626.

Rathore SS, Chandravanshi P, Chandravanshi A, Jaiswal K. Eutrophication: impacts of excess nutrient inputs on aquatic ecosystem. J Agric Vet Sci. 2016;9(10): 89-96. http://iosrjournals.org/iosr-javs/papers/Vol9-Issue10/Nersion-1/ Q0910018996.pdf. (IOSR-JAVS) e-ISSN: 2319-2380, p-ISSN: 2319-2372. Accessed 6 Feb 2018.

Sigee DC. Freshwater microbiology; 2004. https://doi.org/10.1002/0470011254.

Volterra L, Boualam M, Menesguen A, Duguet JP, Duchemin J, Bonnefoy X. European Commission Eutrophication and health Luxembourg: Office for Official Publications of the European Communities $2002-28$ pp. $-21 x$ $29,7 \mathrm{~cm}$ ISBN 92-894-4413-4.

Water Resources Unit. Water resources in Mauritius; ground water resources, main water indicators, 2011-2015 and reservoirs. 2014. http://publicutilities. govmu.org/English/WRU/Pages/default.aspx. Accessed 6 Feb 2018.

Yokota. Unpublished report of research conducted to dermine water quality in PdM reservoir by a Japanese expert for the Central Water Authority Mauritius; 1990.

Ready to submit your research? Choose BMC and benefit from:

- fast, convenient online submission

- thorough peer review by experienced researchers in your field

- rapid publication on acceptance

- support for research data, including large and complex data types

- gold Open Access which fosters wider collaboration and increased citations

- maximum visibility for your research: over $100 \mathrm{M}$ website views per year

At BMC, research is always in progress.

Learn more biomedcentral.com/submissions 